\title{
PELATIHAN BAHASA INGGRIS UNTUK MEMBANGUN PELAYANAN PRIMA PADA STAFF TAMAN BACA KESIMAN
}

\author{
Dewa Ayu Kadek Claria ${ }^{*}$ \\ I Gusti Ngurah Adi Rajistha² \\ 1,2Universitas Warmadewa, Denpasar, Indonesia \\ clariadewaayu@gmail.com ${ }^{\left.1^{*}\right)}$ \\ ngurah.adi.rajistha@gmail.com $^{2)}$
}

Kata Kunci: [Pelayanan Prima; Bahasa Inggris; Pelatihan]

Published by:

\begin{abstract}
Abstrak: Taman Baca Kesiman Bali merupakan perpustakaan umum yang dibuat dengan menerapkan konsep wisata edukasi. Kegiatan yang dilaksanakan di TBK tidak hanya bersifat nasional namun juga internasional sehingga kemampuan para staf di TBK dalam bidang Bahasa Inggris dan pelayanan perlu mendapatkan perhatian. Melalui hasil survey yang telah dilakukan sebelumnya ditemukan bahwa kemampuan para staff di TBK masih perlu untuk ditingkatkan. Setelah pelatihan dilaksanakan dengan mengedepankan beberapa poin penting pada bidang pelayanan, para staf akhirnya dapat mewujudkan konsep pelayanan prima dengan menggunakan bahasa Inggris. Konsep yang telah dikuasai dan diaplikasikan dalam pelayananan oleh staf TBK adalah konsep pelayanan prima dalam bentuk tata cara (manner) baik dari segi penampilan (grooming) dan juga bentuk pelayanan (hospitality) yang telah tertuang dalam bentuk pelatihan penggunaan fungsi bahasa yaitu greetings, address system, asking questions dan solving problems for guest complaint.
\end{abstract}

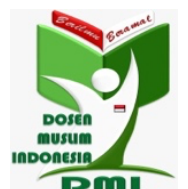

Copyright (C) 2021 The Author(s)

This article is licensed under CC BY 4.0 License (cc) $\mathrm{BY}$ 


\section{Pendahuluan}

Taman Baca Kesiman merupakan sebuah perpustakaan umum yang memiliki terobosan baru dalam bentuk wisata edukasi dengan tujuan untuk menggeser kesan perpustakaan yang kaku. Perpustakaan umum di Bali pada umumnya memiliki kesan yang sangat formal. Berbeda dengan Taman Baca Kesiman atau sering disingkat dengan TBK yang berada di daerah Kesiman tepatnya di Jalan Sedap Malam No. 234 merupakan sebuah perpustakaan umum dengan konsep ruangan terbuka, dalam artian kegiatan membaca dan berdiskusi dapat dilakukan di ruangan terbuka dengan suasana yang lebih santai. Taman Baca Kesiman didirikan pada tahun 2014 oleh pasangan suami-istri yaitu Bapak Agung Alit dan Ibu Hani Duarsa dengan luas lokasi 15 are sehingga konsep perpustakaan dengan ruang terbuka sangat mendukung mengingat lokasi yang cukup luas. TBK dilengkapi dengan kebun yang ditanami berbagai jenis tanaman obat, sayur, bunga dan buah-buahan. TBK dalam upayanya menciptakan konsep perpusatakaan yang santai memiliki dapur yang menyediakan makanan dan minuman. Dapur TBK merupakan pilihan yang digunakan untuk menghindari sebutan cafe karena konsep taman baca yang bukanlah restoran namun hanya sebagai penunjang agar dapat betah dan menikmati buku bacaanya.

TBK menyediakan lebih dari sekitar empat ribu judul buku baik dari jenis fiksi maupun non fiksi. Keunikan yang dimiliki oleh TBK kemudian menjadikan TBK sebagai salah satu pilihan tempat rekreasi di Denpasar. Masyarakat dapat berkunjung dari pukul 10.00 - 18.00 dan semua buku yang disediakan dapat dibaca secara gratis. Pengunjung TBK tidak hanya masyarakat lokal namun juga wisatawan mancanegara, hal ini disebabkan oleh konsep yang dimiliki oleh TBK yang sangat unik dan lokasinya yang berdekatan dengan Desa Sanur dimana banyak wisatawan mancanegara berkunjung dan menginap di wilayah Sanur. Wisatawan mancanegara umumnya gemar membaca sehingga TBK menjadi tempat yang wajib dikunjungi bagi wisawatawn mancanegara yang gemar membaca untuk memperoleh konsep membaca di ruang terbuka yang nyaman yang ditawarkan oleh TBK. TBK sering digunakan sebagai tempat untuk kegiatan kegiatan berbasis komunitas baik dalam rangka bedah buku, kelas menulis, rapat internal, diskusi publik, pemutaran film, hingga konser musik. TBK dikelola oleh 5 orang staff tetap dan 5 orang staff freelance yang mengelola baik dari kebun, perpustakaan, dapur hingga manajemen. Mengingat banyaknya kegiatan yang dilaksanakan di TBK dengan sumber daya manusia yang dimiliki, perlu diadakannya pelatihan bahasa Inggris untuk membangun manajemen pelayanan prima mengingat para pengunjung dan kegiatan yang diselenggarakan tidak hanya berbasis lokal namun juga internasional.

Beberapa industri seperti hotel dan restoran sudah umum kita ketahui memiliki pelayanan yang sangat ramah dan beretika. Perlakuan tersebut merupakan contoh dari pelayanan prima. Pelayanan prima merupakan upaya dari instansi maupun organisasi dalam memberikan pelayanan, informasi dan produk yang dimiliki kepada konsumen sehingga tujuan dari pemilik usaha, instansi atau organisasi dapat berjalan sesuai harapan. Selain pada hotel dan restoran, konsep pelayanan prima juga telah diterapkan penggunaannya oleh para pengemudi taksi. Mengingat Bali sebagai daerah pariwisata, maka konsep pelayanan prima ini sudah diterapkan hampir di setiap sector hanya saja pada beberapa tempat penggunaanya belum maksimal (Dewa Ayu Kadek Claria \& Rajistha, 2020). TBK sendiri memiliki konsep yang unik dengan tujuan yang jelas sehingga perlu dibangun manajemen pelayanan prima dalam bentuk pelayanan berbahasa Inggris mengingat pengunjung yang sebagian besar juga merupakan wisatawan mancanegara. 
Konsep pelayanan prima sendiri terdiri dari attitude, attention dan action. Pelayanan prima apabila diterapkan dengan menggunakan bahasa Indonesia tentu saja akan lebih mudah dilakukan oleh para staff TBK, namun cara menginterpretasikan pelayanan prima dalam bahasa Inggris sangat mendesak untuk dilakukan mengingat kemampuan staff TBK dalam melakukan pelayanan dengan menggunakan bahasa Inggris belum maksimal.

Pelayanan prima merupakan pola layanan dengan mengutamakan kepedulian terhadap kebutuhan pelanggan (Nurlia, 2018). Pelayanan prima ini sangat erat kaitannya dengan mutu sebagai kondisi terbaik dan dinamis yang berhubungan dengan jasa maupun produk (Hardjosoekarto, 1994). Dalam bahasa Inggris pelayanan prima disebut dengan istilah "Excellent Service". Sebagai seseorang yang bekerja di bidang pelayanan perlu mengetahui konsep tersebut untuk memperoleh kepuasan pelanggan (customer satisfaction). Kepuasan pelanggan merupakan tujuan utama dari pelayanan prima. Kata service menjadi strategi sederhana dalam mencapai suatu kesuksesan (Devrye, 1997). Strategi tersebut adalah; Self Esteem (Memberi Nilai pada diri sendiri), Excedd Expectations (Melampaui Harapan Konsumen), Recover, Vision, Improve, Care dan Empower. Pelayanan prima sangat erat hubungannya dengan kualitas dan unsur kualitas dapat berbeda pada setiap individu sehingga perlu diberikan pemahaman unsur kualitas tersebut untuk memperoleh kesamaan persepsi (Tjiptono, 1997).

Melalui hasil survey yang dilakukan, staff di TBK belum memiliki konsep dasar dari adanya pelayanan prima terutama dalam menggunakan bahasa Inggris. Pelayanan yang diberikan oleh para staff di TBK memiliki keunggulan dengan menerapkan konsep kekeluargaan, namun hal tersebut menjadi sulit diterapkan ketika pengunjung merupakan orang asing yang menggunakan bahasa Inggris sehingga pelayanan tidak dapat dilakukan secara maksimal terlebih dapat mencapai pelayanan prima.

Berdasarkan pemaparan tersebut di atas, maka dapat disimpulkan bahwa permasalahan yang dihadapi mitra adalah sebagai berikut;

1. Kemampuan bahasa Inggris yang dimiliki para staff di TBK masih bersifat umum sehingga belum mampu menciptakan konsep pelayanan prima.

2. Konsep pelayanan dalam bentuk kekeluargaan perlu dikembangkan mengingat para Staff di TBK berhadapan dengan pengunjung dari berbagai negara dalam berbagai event atau kegiatan yang dilaksanakan di TBK sehingga perlu dibangun manajemen pelayanan prima untuk meningkatkan citra dari TBK.

\section{Metode Pelaksanaan}

Pelaksanaan kegiatan Pelatihan Bahasa Inggris untuk membangun manajemen pelayanan prima pada staff Taman Baca Kesiman Bali dilaksanakan secara bertahap sehingga mampu menghasilkan pelatihan yang mampu memiliki luaran dan capaian sesuai dengan yang di inginkan. Adapun tahap-tahap dalam pelaksanaan kegiatan ini adalah sebagai berikut;

\section{Pengumpulan data potensi dan masalah}

Dalam mengumpulkan data potensi dan masalah, terdapat dua tahapan yang dilaksanakan. Adapun tahapan tersebut ialah tahap survei lapangan dan tahap wawancara kepada mitra. Tujuan dari diadakanya survei lapangan adalah untuk mengetahui potensi masalah yang dihadapi oleh mitra, sedangkan dalam tahap wawancara, dilakukan pendekatan terhadap 
mitra guna menjalin kerjasama dalam pengabdian kepada masyarkat ini. Semua hal - hal penting terkait dengan data primer kemudian dicatat dan direkam. Setelah mencatat dan merekam data yang telah diperoleh dimasukan ke dalam beberapa bagian permasalahan. Selama proses pengumpulan data, semua kegiatan di dokumentasikan dalam bentuk photo. Sebelum survei ke lapangan dilaksankan telah dibuat sebelumnya list pertanyaan dalam bentuk kuesioner untuk mengukur kemampuan berbahasa staf Taman Baca Kesiman (TBK) sehingga dapat digunakan sebagai acuan dalam memperoleh informasi yang lebih akurat untuk menjawab kebutuhan para staf sekaligus mitra dalam kegiatan perihal materi pembelajaran apa yang dibutuhkan saat ini yang sifatnya mendesak sehingga bisa menjadi prioritas dalam pelaksanaan pelatihan.

\section{Pengolahan data potensi dan masalah}

Data yang telah diperoleh selama pelaksanaan survei dan wawancara kemudian dipilah dan dimasukan sesuai kategori yang telah disiapkan sebelumnya. Dalam hal ini yang diutamakan adalah data primer terkait materi apa yang harus diberikan kepada staff Taman Baca Kesiman (TBK) yang sekiranya dapat meningkatkan kualitas pelayanan yang diberikan oleh staf TBK terutama dalam menggunakan bahasa Inggris. Staff TBK yang terdiri dari 10 orang yang terbagi dan memiliki tugas dan peran yang berbeda dalam pekerjaannya kemudian dipilah lagi materi yang akan disampaikan sehingga dapat memenuhi kebutuhan seluruh staff.

\section{Pelaksanaan}

Berdasarkan hasil dari survey yang telah dilakukan sebelumnya terhadap potensi dan masalah yang dihadapi staf Taman Baca Kesiman Bali, maka Pengabdian kepada Masyarakat dalam bentuk pelatihan bahasa Inggris dengan mengusung konsep manajemen pelayanan prima ini dilaksanakan. Pelatihan bahasa Inggris pada pengabdian ini menitik beratkan pada pelatihan bahasa Inggris khusus di bidang pelayanan dengan menonjolkan penggunaan fungsi - fungsi bahasa khususnya dalam bahasa Inggris yang dikenal dengan istilah language function dan juga dikombinasikan dengan pengetahuan tentang adanya konsep penampilan atau grooming dalam menunjang manajemen pelayanan prima. Peserta pelatihan merupakan staf di TBK yang sebelumnya telah disurvey kemampuan bahasa Inggrisnya. Staf TBK berjumlah sepuluh orang merupakan keseluruhan Staff dengan bidang pekerjaan yang berbeda. Bidang pekerjaan dari kesepuluh orang tersebut yaitu ada yang bertugas sebagai manajer pelaksana, petugas pelayanan, koki dan juga petugas kebersihan.

\section{Hasil dan Pembahasan}

Kegiatan dilaksanakan dalam bentuk pengajaran konvensional dengan tetap mematuhi prosedur kesehatan yang dianjurkan pemerintah selama adanya pandemic Covid-19. Pengajaran dalam bentuk konvesional sangat memungkinkan untuk dilakukan mengingat jumlah peserta dan pelatih tidak melebihi dari aturan serta ruangan pelatihan yang dilakukan di ruang terbuka dengan tetap menjaga jarak. Kegiatan dalam bentuk konvensional dilakukan dalam beberapa tahap.

Pada tahap awal pelatihan dilakukan sebagai proses pengenalan dan diskusi awal. Pada tahap ini, peserta diberikan pengenalan terhadap media apa saja yang akan digunakan dalam pelatihan dan materi yang diberikan yaitu berupa; pelatihan dasar bahasa Inggris dengan mengarah kepada fungsi-fungsi bahasa (language function) yang dikombinasikan ke dalam bentuk bahasa Inggris pelayanan (English for Hospitality) serta mengenalkan secara umum terhadap konsep pelayanan prima. Latihan kecil diberikan 
dalam bentuk pelatihan bagaimana cara memulai suatu percakapan dengan pengunjung dalam bentuk sapaan (greetings) dan juga penamaan (address system). Dalam proses awal pelatihan untuk menerapkan bahasa asing perlu dilakukan pengenalan sebagai proses untuk mengetahui lebih dalam pengetahuan peserta pelatihan terlepas dari proses evaluasi awal untuk mengetahui kebutuhan pengguna (Hutchinson, Tom \& Waters, 1987). Pada proses pelatihan ini digunakan komunikasi dua arah sehingga pendekatan yang dilakukan sangat fleksible dengan memperhatikan keinginan dari peserta pelatihan selama proses pengajaran (Pitana, 2009). Selain menggunakan metode komunikasi dua arah, pelatihan bahasa Inggris di TBK juga menggunakan metode komunikasi persuasif dan imperatif. Komunikasi persuasif digunakan untuk meningkatkan motivasi peserta pelatihan selama pelatihan yang mana bentuk komunikasi persuasif ini dapat memberikan kesan yang ramah dan informatif (Claria, D.A.K \& Sariani, 2020). Sedangkan komunikasi imperatif digunakan selama proses pelatihan untuk mengembangkan kemampuan para peserta dalam mengaplikasikan kemampuan bahasa Inggris yang dimiliki. Kalimat imperatif pada umumnya merupakan kalimat suruhan namun juga dapat memiliki fungsi sebagai bentuk permintaan maupun pemberian izin (D.A.K. Claria, 2021).

Proses evaluasi pada akhir kegiatan dilaksanakan untuk memperoleh umpan balik dan persentase peningkatan kemampuan para pengemudi taksi sebagai peserta pelatihan. Langkah awal dari program ini adalah dengan mengumpulkan data yang terkait dengan kemampuan berbahasa Inggris para staff di Taman Baca Kesiman Bali dengan menggunakan teknik wawancara untuk menganalisis kemampuan bahasa Inggris staf TBK. Evaluasi juga diperoleh dengan menggunakan kuesioner untuk menganalisis kemampuan staff TBK terkait pengetahuan bahasa Inggris seputar etika berbahasa Inggris dalam dunia pelayanan atau Hospitality. Staff TBK diminta untuk mengisi kuesioner terkait kebutuhan materi yang mereka rasa perlukan untuk mengembangkan kemampuan berbahasa Inggris terutama dalam bidang pelayanan dengan tujuan membangun konsep manajemen pelayanan prima.

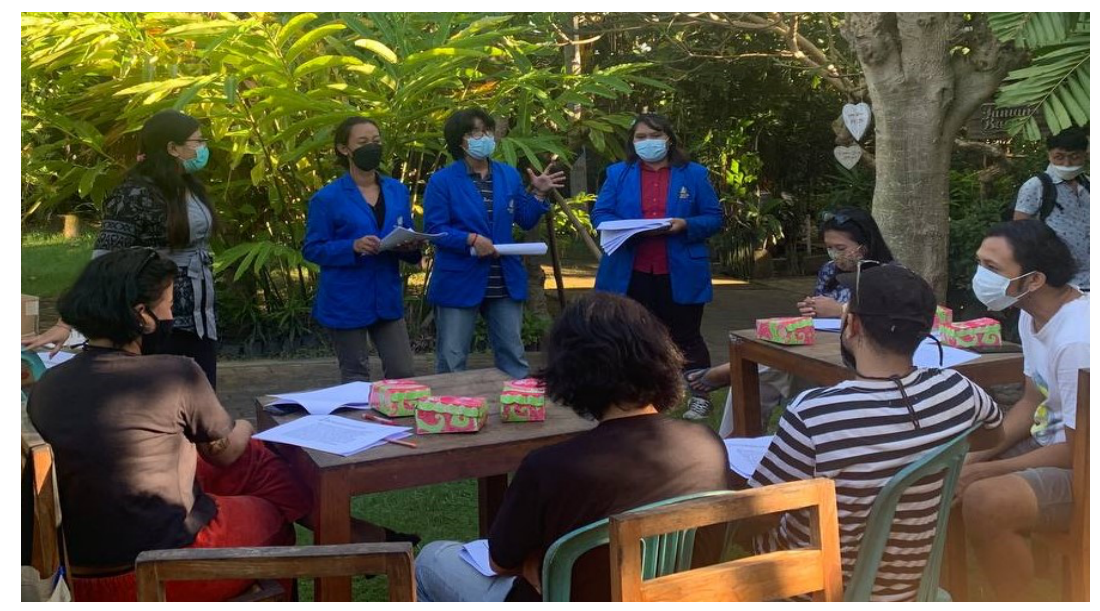

Gambar 1. Pelatihan Bahasa Inggris di Taman Baca Kesiman 


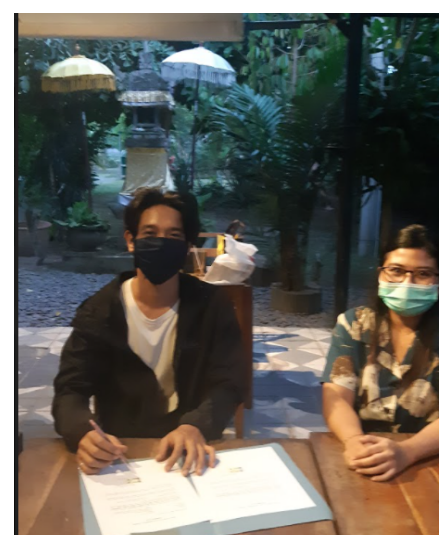

(a)

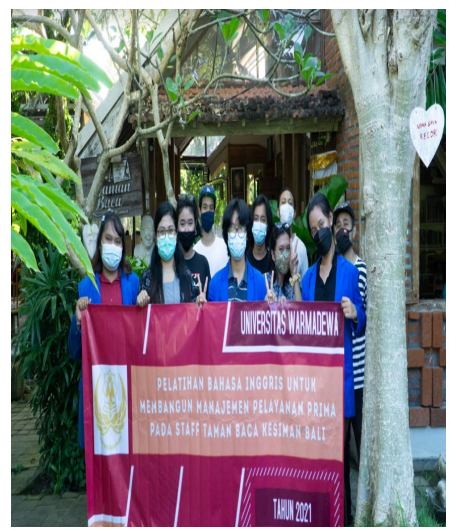

(b)

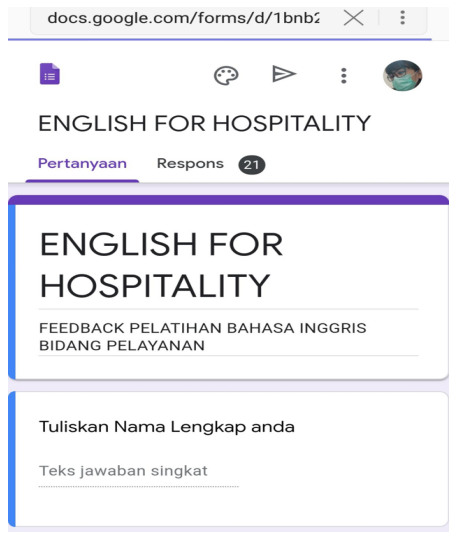

(c)

Gambar 2. Proses Kegiatan (a) survey (b) pelatihan (c) evaluasi

\section{Kesimpulan}

Pengabdian kepada Masyarakat yang telah dilakukan dalam wujud pelatihan bahasa Inggris untuk membangun manajemen pelayanan prima ini menjadikan staf Taman Baca Kesiman sebagai peserta pelatihan atau mitra yang mana pelatihan telah berjalan dengan baik dan lancar. Dari kegiatan tersebut dapat disimpulkan bahwa pelatihan bahasa Inggris dengan metode konvensional di masa pandemi Covid-19 ini berjalan dengan lancar dengan menerapkan protokol kesehatan sesuai dengan yang dianjurkan pemerintah. Pada saat pelatihan materi yang diberikan yaitu berupa bahasa Inggris khusus di bidang pelayanan dengan tujuan untuk meningkatkan kemampuan staf TBK dalam hal pengetahuan manajemen pelayanan prima dan juga kemampuan dalam menggunakan bahasa Inggris sesuai dengan bidang maupun profesi staf di TBK. Melihat perkembangan kemampuan para staf TBK serta antusiasme para staf memunculkan harapan yang sangat besar terhadap pelatihan serupa yang nantinya dapat dilakukan Kembali dengan menyasar para pelaku wisata maupun segenap pekerja di bidang pelayanan yang membutuhkan bahasa Inggris dalam berkomunikasi. Dari adanya keberlanjutan pelatihan serupa yang menerapkan bahasa Inggris untuk membangun manajemen pelayanan prima diharapkan dapat meningkatkan sumber daya manusia di daerah pariwisata sehingga pada akhirnya diharapkan mampu untuk meningkatkan kesejahteraan Bersama.

\section{Ucapan Terimakasih}

Ucapan terima kasih disampaikan kepada Lembaga Pengabdian Masyarakat Universitas Warmadewa atas dukungannya baik berupa dana dan kesempatan yang diberikan sehingga pelaksanaan pelatihan bahasa Inggris ini dapat berjalan dengan lancar. Rasa terima kasih juga disampaikan kepada pihak Taman Baca Kesiman sebagai mitra dalam program Pengabdian kepada Masyarakat ini.

\section{Referensi}

Claria, D.A.K \& Sariani, N. . (2020). Metode Komunikasi Persuasif untuk Meningkatkan Motivasi Berwirausaha Masyarakat di Desa Kesiman Kertalangu pada Masa Pandemi Covid-19. 
https://www.ejournal.warmadewa.ac.id/index.php/licosjournal/article/view/22 81

Claria, D.A.K. (2021). Sosialisasi Penggunaan Kalimat Imperatif sebagai Strategi Pemasaran UMKM pada Masa Pandemi Covid-19 di Desa Pejeng Gianyar. Jurnal Abdidas, 2(3).

Claria, Dewa Ayu Kadek, \& Rajistha, I. G. N. A. R. (2020). Optimalisasi Penggunaan Media Daring dalam Pelatihan Bahasa Inggris Bidang Pelayanan Untuk Para Pengemudi Taksi di Desa Sanur Bali. Dedication: Jurnal Pengabdian Masyarakat, 4(2), 81-91. https://doi.org/10.31537/dedication.v4i2.356

Devrye, C. (1997). Good Service is Good Business: 7 Simple Strategies for Success. Prentice Hall.

Hardjosoekarto. (1994). Beberapa Perspektif Pelayanan Prima. Bisnis Dan Birokrasi, $\operatorname{IV}(3)$.

Hutchinson, Tom \& Waters, A. (1987). English for Spesific Purpose. https://www.academia.edu/4831921/English_for_specific_purposes_hutchinson_ tom_waters_alan

Nurlia. (2018). Strategi Pelayanan dengan Konsep Service Excellent. Meraja Journal, 1(1).

Pitana, I. G. (2009). Pengantar Ilmu Pariwisata. Andi.

Tjiptono, F. (1997). Prinsip-prinsip Total Quality Service. Andi. 